Abstracta Iranica Abstracta Iranica

Revue bibliographique pour le domaine irano-aryen

Volume 28 | 2007

Comptes rendus des publications de 2005

"The Archaeology of the Median Period: an Outline and a research perspective $» . I A, 40,2005$, pp. 315-340.

Rémy Boucharlat

(2) OpenEdition

Journals

Édition électronique

URL : http://journals.openedition.org/abstractairanica/15772

DOI : 10.4000/abstractairanica. 15772

ISSN : 1961-960X

Éditeur :

CNRS (UMR 7528 Mondes iraniens et indiens), Éditions de l'IFRI

Édition imprimée

Date de publication : 15 mai 2007

ISSN : 0240-8910

Référence électronique

Rémy Boucharlat, « "The Archaeology of the Median Period: an Outline and a research perspective ». IA, 40, 2005, pp. 315-340. », Abstracta Iranica [En ligne], Volume 28 | 2007, document 86, mis en ligne le 18 septembre 2007, consulté le 25 septembre 2020. URL : http://journals.openedition.org/ abstractairanica/15772 ; DOI : https://doi.org/10.4000/abstractairanica.15772

Ce document a été généré automatiquement le 25 septembre 2020.

Tous droits réservés 


\title{
"The Archaeology of the Median Period: an Outline and a research perspective ». IA, 40, 2005, pp. 315-340.
}

\author{
Rémy Boucharlat
}

Cette mise au point se place dans la tendance actuelle de la recherche, qui consiste à mettre en doute l'existence d'un État mède et d'un art mède identifiable (voir la position opposée de Sh. Razmjou, c.r. $n^{\circ} 112$ ). On notera, à son crédit, que l'A. tient cette position depuis longtemps, comme S. Brown, sans pourtant avoir eu connaissance de l'ouvrage important édité par Lanfranchi, Rollinger et Roaf en 2003 (cf. Abs. Ir. 26, c.r. $\mathrm{n}^{\circ}$ 117). B.G. n'envisage pas la création d'un État mède dans l'ultime phase de la période mède, après la chute de Ninive, à la différence d'autres archéologues, comme D. Stronach et M. Roaf dans le volume cité ci-dessus, où ils sont minoritaires par rapport aux historiens des textes. Mais l'A. ne nous explique pas la relation qu'il semble établir entre le problème mède et celui de la date de la séparation entre Iraniens et Indo-Aryens, ou encore les travaux archéologiques conduits ces dernières années dans le Turkménistan méridional.

\section{INDEX}

Thèmes : 3.2.2. Pré-Achéménides et Achéménides 
AUTEURS

RÉMY BOUCHARLAT

IFRI / CNRS - Téhéran / Lyon 